\title{
A Brief Analysis of Subtitle Translation Based on the Intercultural Perspective-A Case Study of Kung Fu Panda
}

\author{
LIU Xin, XIONG Shuhui \\ University of Shanghai for Science and Technology, Shanghai, China
}

\begin{abstract}
Films and television programs are playing an irreplaceable role in serving as the carrier of culture. With the rising of China's national strength, language and culture have changed in some ways in the process of external exchange, which in turn gives an impetus to the international popularity of Chinese culture. In the case of movie $\mathrm{Kung} F u$ Panda, the thesis mainly focuses on the movie subtitling with related to the Chinese characteristics as well as the English translations that deal with the Chinese culture. Through the comparative analysis of the three versions, this paper compares the subtitle translation between Chinese and English from a cross-cultural perspective, so as to further demonstrate the influence of Chinese culture on English films.
\end{abstract}

Keywords: intercultural communication, Kung Fu Panda, subtitle translation

\section{Introduction}

In the recent years, the popularity of Chinese culture and the release of so many foreign films with plenty of Chinese elements have rendered Chinese culture more and more important. In this thesis, I will try to analyze and compare three different translated versions of subtitles of the movie Kung Fu Panda with the purpose of discussing different methods of translating China English and demonstrating the influence of Chinese culture on the film subtitle.

\section{Chinese Elements in Hollywood Movies}

Chinese characters began to appear in American films in the end of 19th century. We can only see the poverty, ignorance, and numbness of these characters. Since the Cold War, American directors prefer to laugh at China through the details of the film. However, Chinese elements are becoming more and more active and attractive. Nowadays, many of Hollywood's biggest films are incorporating a greater number of Chinese elements into them. The following is a list of these elements.

\section{The Chinese Characters}

More and more Chinese actors and actresses achieved international stardom and exerted greater influence on the international stage. In addition to the common supporting roles, Chinese actors and actresses have more opportunities to be the leading roles than before.

LIU Xin, Master, College of Foreign Languages, University of Shanghai for Science and Technology, Shanghai, China. XIONG Shuhui, Ph.D., English Department of College of Foreign Languages, University of Shanghai for Science and Technology, Shanghai, China. 


\section{Symbols of China}

Kung fu and panda seem to be two typical elements related to China; this also shows that in the film. In Ice Age 2, the squirrel sounds much like Li Xiaolong's screams in his film. The iconic pose of Keanu Reeves is bent backwards in The Matrix, a classic of kung fu master Huang Feihong in real life.

\section{The Subtitle Translation of Kung Fu Panda}

Kung Fu Panda is a masterpiece of Hollywood which mixes lots of Chinese cultural elements to Chinese cultural images. In the following parts, the examples of translation from three versions: DVD, FRTVS (风软字 幕组), TEL (TEL字幕组), will be analyzed in detail.

\section{The Brief Review of the Movie}

The story of Kung Fu Panda is set in the Valley of Peace, a martial arts master-studded place of ancient China. Panda Po has always dreamed of becoming a "Kung Fu Emperor" since childhood. One day, word comes that the aged Mater Shifu would select Dragon Warrior at the Jade Palace. Po is accidentally involved in this martial arts competition held among the Furious Five and unexpectedly selected as the Dragon Warrior responsible for defeating escaped prisoner snow leopard Tarou and saving the Valley of Peace.

\section{Culture-Loaded Words}

As Kung Fu Panda sets in ancient China, there are lots of expressions heavily loaded with the Chinese culture. These elements should be rendered in a way that makes the Chinese audience feel at ease. This film reflects the Chinese social and cultural life, so its dialogue often contains the words with Chinese characteristics.

Culture-loaded words are words with unique national cultural connotations as well as social cultural significance based on original meaning or conceptual meaning. Culture-loaded words require translators to precisely convey semantic information in original language, and simultaneously maintain original cultural features to the uttermost. During translation process, translators have to consider multiple factors such as original language features, translation objective, and target reader features and find best translation techniques as far as possible. Targeted at relatively great discrepancy in English cultural translation, there are four translation strategies in culture-loaded word translation.

(1) Foreignization: maintaining connotations of original language culture by literal translation method or transliteration method.

(2) Domestication: realizing functional equivalence by free translation method or replacing inaccessible or ambiguous culture words.

(3) Integration: illustrating original language and maintaining cultural connotations of original language for the convenience of audiences.

(4) Deletion: reducing inference of subtitle on acoustic image by directly deleting culture words hard to translate and unassociated with textual coherence.

Proper names. The names of characters in the films should be as rendered in a Chinese way to make the Chinese audiences feel cordial as possible, written in a way as if they were originally written in Chinese.

The following table lists three versions of subtitle translation: 
Table 1

Four Versions of the Name Translation

\begin{tabular}{lllll}
\hline Names of roles & Literal translation & DVD & FRTVS & TEL \\
\hline Po & 波 & 阿宝 & 阿波 & 阿宝 \\
Monkey & 猴子 & 金猴 & 猴子 & 金猴 \\
Crane & 鹤 & 仙鹤 & 仙鹤 & 仙鹤 \\
Viper & 毒蛇 & 灵蛇 & 毒蛇 & 灵蛇 \\
Tigress & 母老虎 & 娇虎 & 老虎 & 娇虎 \\
Mantis & 螳螂 & 螳螂 & 螳螂 & 螳螂 \\
Tai Lung & 太郎 & 大龙/黑豹太郎 & 泰狼 & 龙 \\
Zeng & 曾 & 小善 & 飞鸽 & 小善 \\
The Furious Five & 暴怒的五人 & 盖世五侠 & 无畏五侠 & 威猛五侠 \\
The Dragon Warrior & 龙战士 & 神龙大侠 & 神龙武士 & 神龙大侠 \\
Whispering Warriors & 低语武士 & 昵喃武士 & 低语武士之莭 & 昵喃武士 \\
Tenshu Army & 藤树军队 & 天守大军 & 天书军 & 天守大军 \\
Master Flying Rhino & 飞行犀牛师傅 & 飞犀牛大侠 & 飞行犀牛大师 & 飞天犀牛大师 \\
Jade Palace & 玉石殿 & 翡翠宫 & 翡翠宫 & 翡翠宫 \\
\hline
\end{tabular}

\section{Example 1}

\section{Po and Zeng}

From Table 1, it can be seen that literal translation may be rigid, making the roles lose their lively character and attraction.

In DVD version, the main character Po’s name is translated to “宝” instead of transliteration of “波”. The origin of “Po" can be explained by the film creators through the transliteration of Chinese word “宝” as “Po”, because the word “宝” itself in Chinese is a popular word which was given the meaning of "hold something or somebody in high esteem”. The addition of “阿” conforms to the way Chinese people name their children, usually with two characters.

\section{Example 2}

\section{Master Oogway \& Shifu}

The tortoise is generally regarded as a symbol of longevity and representative of wisdom in Chinese traditional culture. Because of its longevity, it can experience the life progress that many other creatures cannot undergo. In Kung Fu Panda, a venerable master is a tortoise; he is Po’s Shifu and called "Master Oogway" which is translated into “乌龟大师”. He is also the represent of reigns supreme and the incarnate of wisdom. Using the Pinyin transliteration words “乌龟大师” directly, obvious, this word is very strange to foreign audience, but just due to this strange pronunciation and spelling form that can arouse the curiosity of audience and experience the mysterious state of master. Why not called this role "Master Tortoise"? Because tortoise is a slow, ugly, and common animal in western cultural image, the use of the strange Chinese transliteration word can add to make that image more mysterious and exotic.

Another Chinese transliteration words is "Master Shifu". "Master Shifu" reflects the cultural images which indicate "teacher's dignity" totally by the pronunciation. The word "Shifu" directly used in the film shows the profound influence of Chinese culture to the world culture. It can even be predicted that in the future, Shifu will become a member of the English vocabulary.

Example 3

The Furious Five 
"Furious" always is marked by extreme and violent energy, which gives people a power of justice. If literal translated the word into Chinese: “暴怒的”, it may lose its grandeur. But if translated it into “威猛”, “无 畏”, and “盖世”, then a brave and justice image stands vividly on the paper.

“侠” is a character very familiar to the Chinese audience and it is often used to refer to heroes. The two translations demonstrate the superior kung fu skills and their strong sense of justice.

\section{Example 4}

The Dragon Warrior

"Dragon" has always been a controversial image in the eyes of scholars, because "Dragon” in the western cultural image is nothing but an evil creature which has huge wings and powerful force. In Kung Fu Panda, Panda Po was selected by Master Oogway as the "Dragon Warrior" which was a very noble and righteous title in everyone's eyes. The use of "Dragon" in the film has been completely sinicized, due to that fact that it absorbed and advocated Chinese elements actively. So the word "Dragon" can be regarded as the Chinese English.

\section{Example 5}

\section{The Jade Palace}

“Jade” means “玉” in Chinese. But translating “The Jade Palace” into “玉宫” may be a little stiff. Since the film is set in ancient China, the rendering to “翡翠” fits in the style of the grand palace and makes audiences to be charmed by the quaintness of the picture.

Terms related to kung fu. China is famous for its profound culture of kung fu all over the world. There are many fight scenes and kung fu terms in this film. A large number of kung fu words are used and they should be translated back to Chinese by using special kung fu terms that are often used in Chinese Wuxia films and series.

Table 2

Other Kung Fu-Related Expressions

\begin{tabular}{llll}
\hline Names of kung fu & DVD & FRTVS & TEL \\
\hline The Dragon Scroll & 神龙秘笼 & 神龙手卷 & 神龙秘籍 \\
Feet of Fury & 佛山无影脚 & 佛山无影脚 & 愤怒之脚 \\
The Invisible Trident of Destiny & 隐形天命三叉戟 & 隐形命运网 & 隐形天命三叉戟 \\
The Wuxi Finger Hold & 无极拈花指 & 弹指神功 & 无须铁指扣 \\
Wings of Justice & 正义之翼 & 正义之翼 & 正义之翼 \\
\hline
\end{tabular}

\section{Example 6}

\section{The Dragon Scroll}

These two versions all show the tradition that Chinese people are very worshiping the dragon and kung fu myths. The addition of “神” and “秘” make the translation not only a four-character expression in conformity with the way of expression in Chinese but also is closer to Wuxia.

Example 7

\section{Feet of Fury}

If literal translated “Feet of Fury” to “愤怒之脚”, it would be displayed too straightforwardly. The translator uses the commonly-used term of kung fu in Chinese, “佛山无影脚”, which is straight to the point and easy for the Chinese audience to gasps the point. 
Example 8

The Wuxi Finger Hold

Although these three versions all reflect the skill of Wuxia, but “无极拈花指” not only can show the power of fingers completely, but also is romantic and rich in poetry.

\section{Linguistic Elements}

Apart from numerous adoptions of typical Chinese English represented by transliterated words, there are also considerable expressions carried with Taoist culture in the film. Though the cultural images of Taoism which has influenced China for thousands of years seem vague here, they are well organized into a systematical structure. In this film, Oogway is delineated as the incarnation of the sage with paramount power. Though tacit and silent, he always says classical sentences worthy of pondering. In another word, his words are filled with the connotations and doctrines of Chinese Taoism such as "passive inaction" and "following the divine Tao". As a result, these words and expressions can be studied as Chinese English.

\section{Example 9}

"One often meets his destiny on the road he takes to avoid it."

A: 予欲避之, 反促遇之。(DVD)

$\mathrm{B}$ : 人算不如天算, 是福不是祸, 是祸躲不过。(FRTVS)

C: 越想逃避宿命, 越会在半道上和宿命撞个正着。(TEL)

When Master Shifu is ordering to "double the guards, double their weapons, double everything” to prevent Tai Lung escaping from the prison, Master Oogway says this sentence.

Words of Oogway are in conformity with the ideology of "following the divine Tao". He himself is a tranquil man in pursuit of inner peace and he also persuades others to follow the doctrine. Although adopting the same strategy — domestication, they are expressed in different forms: Version A uses classical Chinese, the form of ancient Chinese literary style; In Version C, “宿命” means predestination, which is used by the Chinese people to say something is predetermined and one has to accept it; and Version B employs a popular Chinese saying. The three versions are all close to the life and culture of the Chinese people and easy for them to understand.

Version B is much easier to understand: When the audience are reading this translation, they will grasp its meaning just by a glimpse of it since it is made of two sense groups, two famous Chinese proverbs “人算不如 天算” and “是福不是祸, 是祸躲不过”. Version A is the best among the three due to that it uses the least words but best conveys the profound meaning of Master Oogway.

\section{Example 10}

Master Shifu is worried and restless that Tai lung is going to come back and take his revenge when Master Oogway says, "Your mind is like this water my friend. When it is agitated it becomes difficult to see. But if you allow it to settle...the answer becomes clear".

A: 你心如此水, 老朋友, 乱则不明。但若心如止水, 答案便尽现眼前。(DVD)

B: 你的心与这潭水一样, 激动的时候很难看清。但你若让它平静下来, 答案就变清楚了。(FRTVS)

$\mathrm{C}$ : 你的思绪就像这池水, 朋友, 稍有外界触动就很难清澈明朗。可如果让它静下来, 答案顿时变 得清晰了。(TEL)

Version A is a comparatively good translation by using four-character such as “心如此水”, “乱则不明”. It is not only because that the Chinese people prefer the four-character words in their writing, but also because 
these concise words are in line with the identity of Master Oogway as the embodiment of wisdom. Version B and $\mathrm{C}$ are stated flatly, nothing out of the ordinary.

Tracing back to this sentence's in-depth connotation that human should patiently perceive the essence of "passive inaction", this profound meaning also reflects in the way Master Shifu teaches Po: "One of Master Oogway's final teachings is inner peace". By referring to innermost tranquil, the concept of "inner peace" exactly coincides with the manner of Taoism and the doctrine of "passive inaction". The key of Po's defeat over the potent opponent is his final comprehension about "inner peace". Audiences can fully sense the reflections of "passive inaction" written in Tao Te Ching and understand that people could only become strong and cultivate a supreme mindset after forsaking behaviors going against Taoism.

However, from another perspective, there still exists a trivial difference between "inner peace" emphasized by the film and "harmony between man and nature" and "forgetting everything" advocated by Chuang Tzu. People could only enter into a selfless realm and perceive the profound meaning of "the unity of Zen and universe” and important life philosophy by undergoing sufferings and hardships. In a short time, Po could not reach such a supreme realm in nature. However, he seems to be trained as a superman to defeat the powerful enemy. This is a typical Hollywood hero, whereas swordsman in China must undergo a rather long time of training to make achievements and radical changes. In this sense, this film has a misunderstanding about the "harmony between man and nature" concept of China.

\section{Conclusion}

With the spreading of English and the rapid development of the economy, policy, and culture, Chinese English emerges in all aspects of social realm. As mentioned by Xie Tianzhen (1999, p. 184): "cultural image is a kind of cultural symbol characteristic of relatively fixed and unique cultural connotations and sometimes abundant and profound associations. Therefore, as long as people mention it, they will quickly understand one another”. For this reason, Kung Fu Panda achieves the best fusion and communication between Chinese and western culture in the dialogue, linguist, culture, and communication which fully appeal to the Chinese audience's aesthetic taste. The great success of the animated film revolutionized translation circle's view of subtitle translation; this film is a typical representative of the successful subtitle translation.

\section{References}

Li, W. Z. (1993). China English and Chinese English. Foreign language teaching and research, 4, 64.

Li, Y. X. (2001). Strategies for subtitle translation. The Chinese translation, 4, 39.

Ma, Z. Q. (2005). Introduction to film and television translation. Beijing: Communication University of China press.

Sdriana, S. (2004). Introduction to audionvisual translation. Leeds: University of Leeds.

Titford, C. (1982). Subtitling: Constrained translation. Lebende: Sprachen.

Xie, T. Z. (1999). Medio-translatology. Shanghai: Shanghai Foreign Language Education Press.

Zhu, X. (2013). Intercultural communication factors in the translation of subtitles in Kung Fu Panda. Jinan: Shandong Normal University. 